\title{
The yield and nutrient content of colostrum and milk of women from giving birth to 1 month post-partum
}

\author{
BY L. SAINT, MARGARET SMITH ${ }^{1}$ AND P. E. HARTMANN \\ Department of Biochemistry and ${ }^{1}$ Department of Obstetrics and Gynaecology, University \\ of Western Australia, Nedlands, Western Australia 6009, Australia
}

(Received 23 August 1983 - Accepted 17 February 1984)

1. The intake of mammary secretion from delivery to day 5 post-partum was determined by test-weighing nine infants using an integrating electronic balance. The mean yield of colostrum for the first $24 \mathrm{~h}$ after birth was $37 \cdot 1$ (range 7.0-122.5) $\mathrm{g}$ and was 408 (range $98 \cdot 3-775$ ) and $705 \cdot 4$ (range $452 \cdot 5-876$ ) $\mathrm{g} / 24 \mathrm{~h}$ on days 3 and 5 post-partum respectively.

2. The milk yield of mothers on either day 14 or 28 post-partum was determined by test-weighing the mother. The mean milk yield was $1 \cdot 156(\mathrm{SD} 0 \cdot 167) \mathrm{kg} / 24 \mathrm{~h}$.

3. A significant correlation $(P<0.001 ; r 0.85, n$ 42) was found between milk yield measured by test-weighing the infant and milk yield measured by test-weighing the mother, confirming that it is possible to obtain a similar estimate of milk consumed using either of the two methods of test-weighing.

4. There was a significant positive correlation $(P<0.001)$ between lactose concentration and milk yield for the first $5 \mathrm{~d}$ post-partum $(r 0.76, n 22)$; a significant negative correlation $(P<0.001)$ between protein concentration and milk yield $(r-0.74, n 22)$ and no significant correlation between fat concentration and milk yield for the period studied.

5. The calculated energy intake of infants during the first $24 \mathrm{~h}$ after birth was only $0 \cdot 12($ range $0 \cdot 02-0 \cdot 29) \mathrm{mJ}$. This increased to 1.44 (range $0 \cdot 83-2 \cdot 18$ ) and 2.99 (range $2 \cdot 49-4 \cdot 06$ ) $\mathrm{mJ} / 24 \mathrm{~h}$ by days 3 and $14-28$ post-partum respectively.

The abrupt increase in the concentration of lactose in the mammary secretion just before parturition has been shown to be a useful indicator of the increase in the synthetic activity of the mammary glands of rats (Nicholas \& Hartmann, 1981) and cows (Hartmann, 1973) during the initiation of lactation. In contrast to other species, the concentration of lactose in the mammary secretion of women remains low during late pregnancy and increases abruptly between 30 and $40 \mathrm{~h}$ after parturition (Kulski \& Hartmann, 1981). However, the mothers' observation of the timing of milk 'coming in' suggests that the initiation of lactation begins $72 \mathrm{~h}$ after giving birth in most women (Kulski et al. 1981).

Roderuck et al. (1946) measured milk yield in ten women who fully expressed their breasts for the first $10 \mathrm{~d}$ post-partum. These workers reported that women were able to express an average of only $35.6 \mathrm{ml}$ milk from their breasts during the first $24 \mathrm{~h}$ after birth compared with $577.7 \mathrm{ml}$ on the $3 \mathrm{rd}$ day post-partum. Although these findings are consistent with the change in the concentration of lactose observed by Kulski \& Hartmann (1981), they do not agree with the mothers' observation of the time of milk 'coming in' (Kulski et al. 1981).

An integrating electronic balance was used in the present study to measure the intake of mammary secretion by the infant from birth to day 5 post-partum. These measurements permitted the relationships to be established between the increase in milk yield and the progressive changes in milk composition (particularly lactose) during the initiation of lactation in women.

\section{EXPERIMENTAL}

\section{Women}

Nine women who elected to breast-feed their infants provided informed consent to participate in the study. The women were recruited in late pregnancy and were selected on the basis that they had uncomplicated pregnancies and each expressed a keen intent to 
Table 1. Details of the mothers studied

\begin{tabular}{|c|c|c|c|c|}
\hline Mother & $\begin{array}{l}\text { Age of mother } \\
\text { (years) }\end{array}$ & Parity & Medication & Sex of child \\
\hline$A_{1}$ & 31 & 2 & $\begin{array}{l}\text { Syntocinin } \\
\text { Epidural }\end{array}$ & Male \\
\hline$A_{2}$ & 30 & 2 & Syntometrine & Male \\
\hline$A_{3}$ & 31 & 2 & $\begin{array}{l}\text { Syntocinin } \\
\text { Pethidine }\end{array}$ & Male \\
\hline $\mathrm{A}_{4}$ & 32 & 2 & $\begin{array}{l}\text { Maxalon } \\
\text { Syntometrine }\end{array}$ & Female \\
\hline $\mathbf{A}_{5}$ & 24 & 1 & Syntometrine & Female \\
\hline$A_{6}$ & 29 & 2 & Syntocinin & Male \\
\hline $\mathbf{A}_{\mathbf{8}}$ & 33 & 5 & Syntocinin & Male \\
\hline$A_{11}$ & 26 & 1 & $\begin{array}{l}\text { Syntocinin } \\
\text { Pethidine }\end{array}$ & Female \\
\hline$A_{12}$ & 31 & 2 & $\begin{array}{l}\text { Maxalon } \\
\text { Syntocinin } \\
\text { Pethidine } \\
\text { Phenergan }\end{array}$ & Female \\
\hline
\end{tabular}

breast-feed. All the women had normal deliveries at term. Details of the mothers studied and medications administered during and after labour are shown in Table 1. All mothers studied were discharged from the maternity hospital fully breast-feeding their infant and were fully breast-feeding their babies when studied on either day 14 or day 28 post-partum. Milk yields and samples taken during the first $24 \mathrm{~h}$ following delivery were designated 'day 1 '.

\section{Milk yield}

The milk yield of each mother was determined by the increase in weight of the infant at each breast-feed from delivery to day 5 post-partum inclusive. Test weighings from delivery to day 5 post-partum were performed in the maternity hospital (King Edward Memorial Hospital for Women, Western Australia) using the integrating electronic balance (K36 Mettler balance; Watson Victor, Australia). The mothers were assisted with the infant test-weighings immediately after delivery, thereafter most of the weighings were recorded by the mothers. Two mothers withdrew after completing day 3 of the study. One woman withdrew after completing day 5 of the study. The three women who withdrew from the study all continued to breast-feed their infants successfully but terminated their involvement because: the study was too demanding $\left(A_{5}\right)$; mother discharged herself from hospital $\left(A_{4}\right)$; mother moved away from Perth $\left(A_{3}\right)$. Six women participated in a follow-up study performed in their homes on either day 14 or day 28 post-partum. The milk yield of the mothers participating in the follow-up study was determined by measuring the decrease in the weight of the mother at each breast-feed over a period of $24 \mathrm{~h}$ with a beam balance (type 3550-AAA balance; Avery Australia Limited) (Rattigan et al. 1981).

Four mothers (M1, M2, M3 and M4 aged 32, 26, 26 and 27 years respectively; parity $2,1,1$ and 1 respectively) participated in a study to compare the two methods used to measure milk yield. The mother's decrease in body-weight during each breast feed was determined using the method of Rattigan et al. (1981) and the increase in the body-weight of her infant was also determined on the Mettler integrating balance. A total of forty-two paired weighings were performed. Milk yield measured by the increase in infant weight was closely related to that measured by the decrease in maternal weight (Fig. $1 ; r 0.85$, $P<0.001)$. The equation of the line was $Y=25.66+1.00 X$ where $X$ is the increase in infant 


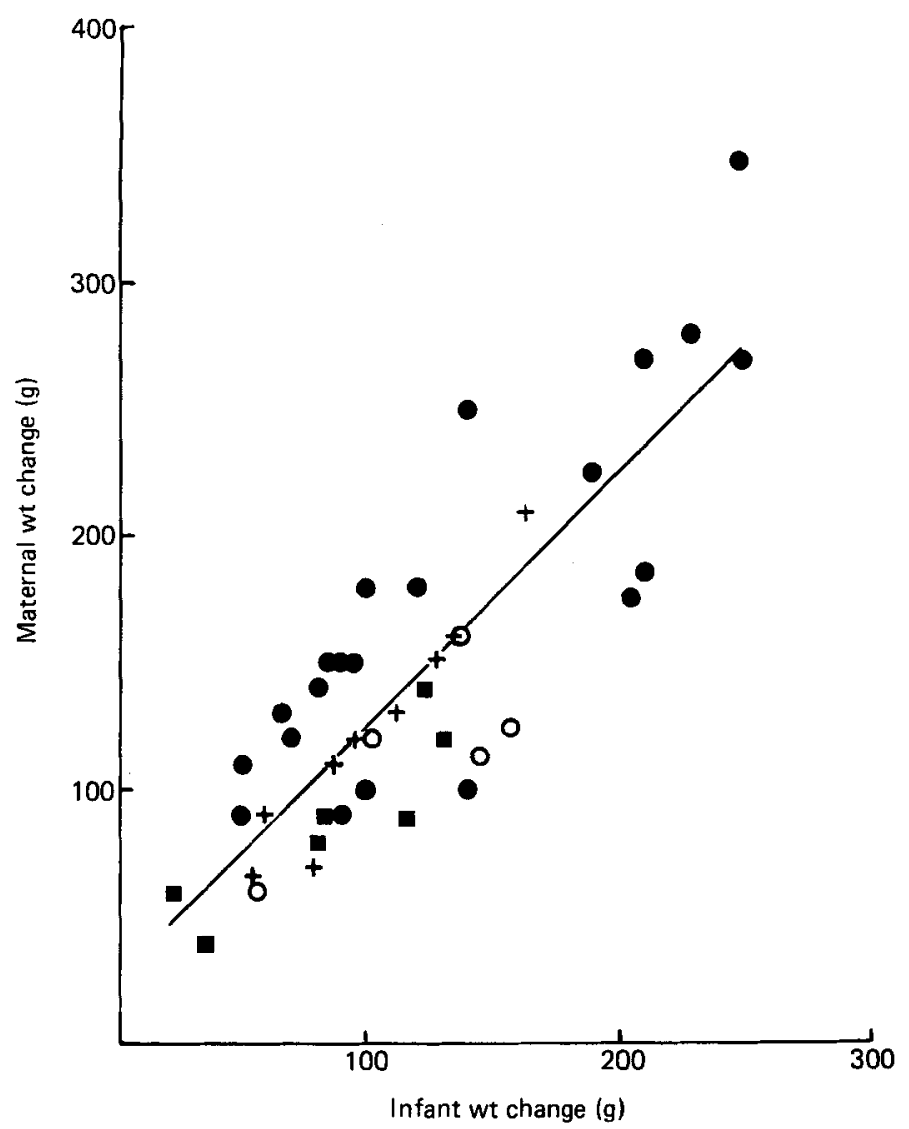

Fig. 1. Relationship between the increase in infant weight (g) and the simultaneous decrease in maternal weight (g) measured using an integrating Mettler balance and the method of Rattigan et al. (1981) respectively in four mother-infant pairs: $M_{1}(O), M_{2}(D), M_{3}(+), M_{4}(O)$.

weight and $Y$ is the decrease in maternal weight. The errors for the intercept and the slope together with the sample standard deviation of the regression coefficient were $12 \cdot 7,35.9$ and 0.098 respectively.

\section{Milk composition}

Samples of mammary secretions $(0 \cdot 1-0.5 \mathrm{ml})$ were collected by manual expression from the right and left breasts before (fore-sample) and immediately after (hind-sample) breast feeds from delivery to day 5 post-partum. Mothers $A_{3}$ and $A_{8}$ collected fore- and hind-samples from the right and left breasts at each feed for the period studied. Mothers $A_{6}, A_{11}$ and $A_{12}$ collected samples from each breast at twelve-hourly intervals from delivery. Mothers $A_{1}, A_{2} A_{4}$ and $A_{5}$ did not collect milk samples for analysis.

The concentration of lactose and total protein in the milk samples was assayed as described previously (Hartmann \& Kulski, 1978). Total triglyceride concentration of the fore- and hind-milk samples was analysed using a modification of the method of Martin (1975).

Estimation of the average concentration of fat in the milk taken in by the infant at each breast feed (mixed milk) was calculated using the following equation:

$$
Y=0.61 X_{1}+0 \cdot 58 X_{2}-0 \cdot 273
$$




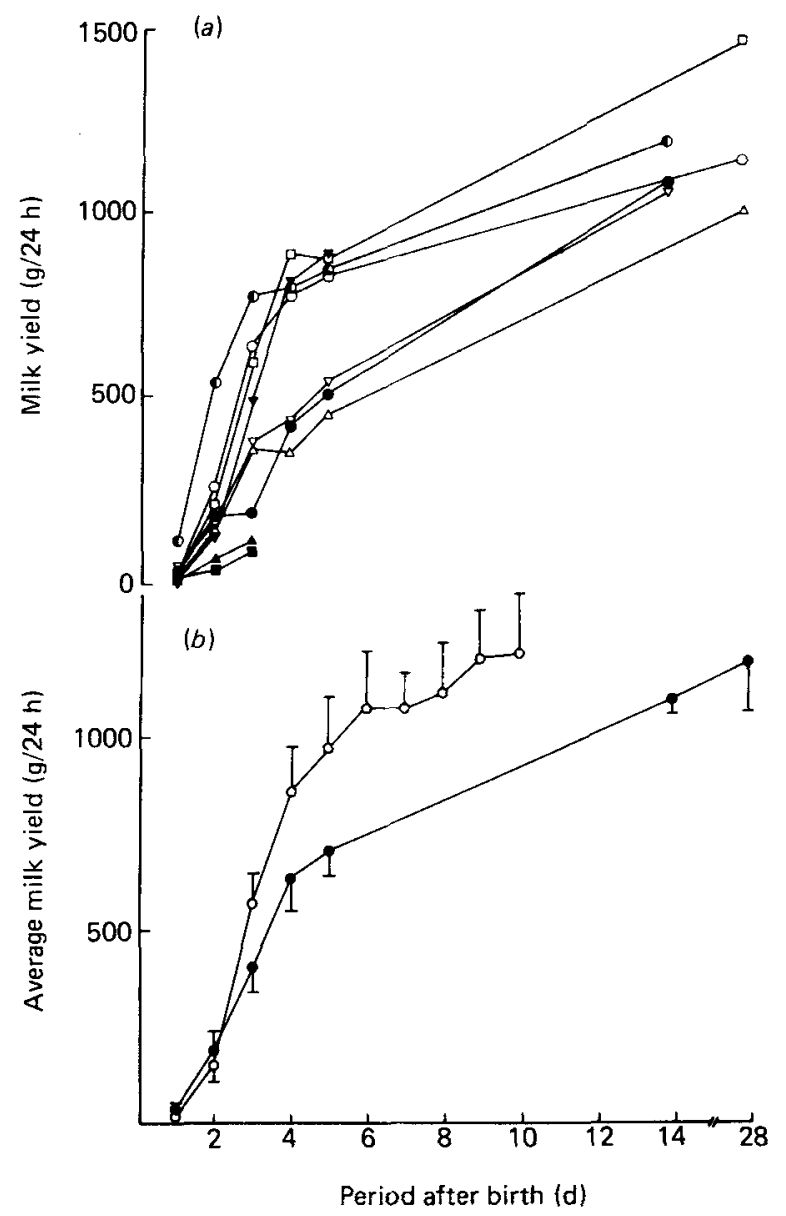

Fig. 2. (a) Progressive changes in the milk yield (g/24h) of nine mothers $\left(A_{1}(O), A_{2}(\bullet), A_{3}(\nabla), A_{4}(\square)\right.$, $A_{5}(\Delta), A_{6}(\square), A_{8}(D), A_{11}(\triangle)$ and $\left.A_{12}(\nabla)\right)$ studied from birth of infant to 1 month post-partum. Mothers $\mathrm{A}_{2}, \mathrm{~A}_{4}$ and $\mathrm{A}_{5}$ received the drug Syntometrine following delivery. (b) Comparison of the milk yield $(\mathrm{g} / 24 \mathrm{~h})$ measured by test-weighing the infant $(O)$ and the breast-expression values of Roderuck $e t$ al. $(1946)(O)$. Points are mean values with their standard errors represented by vertical bars.

where $X_{1}$ is the triglyceride concentration in fore-milk, $X_{2}$ is the triglyceride concentration in hind-milk and $Y$ is the triglyceride concentration in mixed milk. The equation was derived by S. Rattigan and P. E. Hartmann (personal communication) from the relationship between the concentration of fat in fore-, hind- and mixed milk from six women who fully expressed one of their breasts at intervals of $4 \mathrm{~h}$ for $24 \mathrm{~h}$.

The energy content of breast milk was calculated by assuming the energy content of milk lactose, protein and fat to be 17.4, 23.4 and $39 \mathrm{~kJ} / \mathrm{g}$ respectively (Maynard \& Loosli, 1956).

\section{Statistical analyses}

All statistical analyses including standard deviation and standard error of the mean, Student's $t$ test and correlation coefficient were performed as described by Snedecor \& Cochran (1978). 


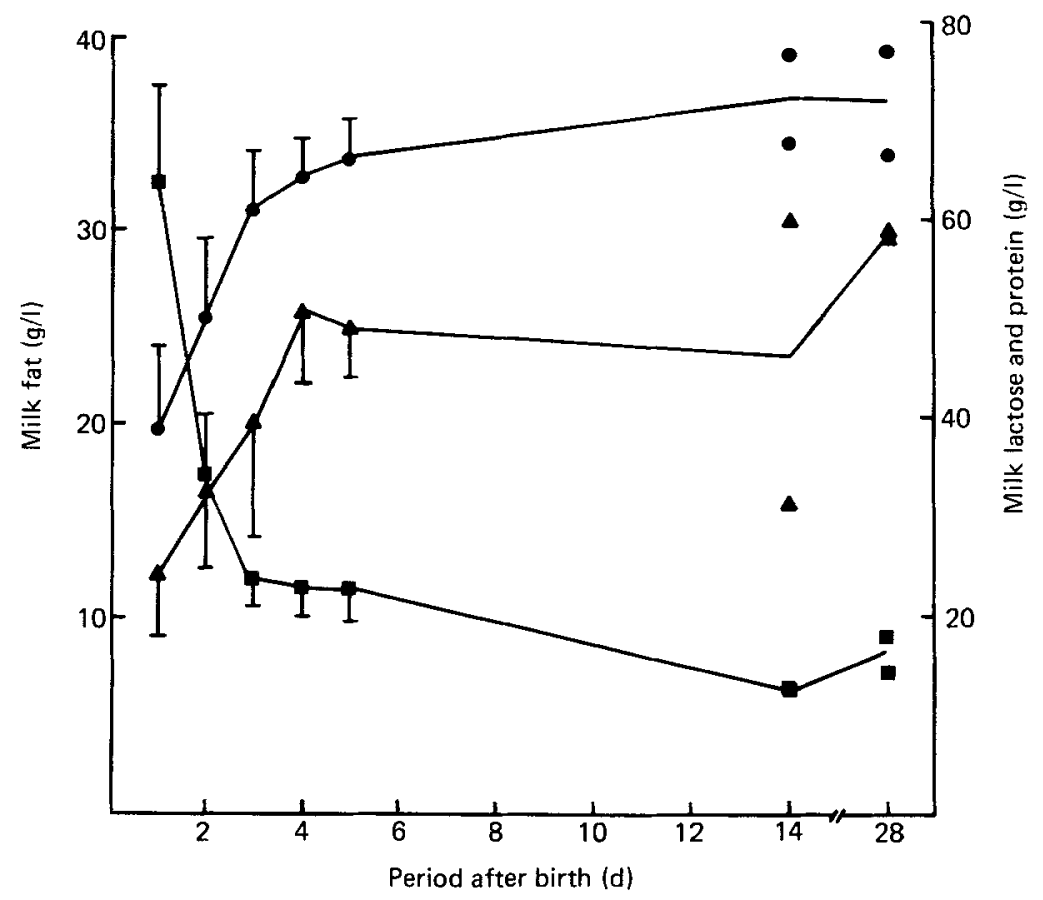

Fig. 3. Changes in the concentration of lactose (O), protein ( $\square)$ and fat $(\boldsymbol{\Delta})$ in the mammary secretions of five mothers from birth of infant to day 28 post-partum. The values obtained for the right and left breasts for each woman $\left(A_{3}, A_{6}, A_{8}, A_{11}, A_{12}\right)$ were averaged and used to calculate the mean for each $24 \mathrm{~h}$ period. Points are mean values with their standard errors represented by vertical bars. On day 14 and day 28 post-partum, values for the individual women are presented.

\section{RESULTS}

Milk yield

The daily milk yield for each of the women studied is shown in Fig. $2 a$. The mean yield of colostrum for the first $24 \mathrm{~h}$ after birth was $37 \cdot 1$ (range 7-122.5) $\mathrm{g}$ and this increased to 408 (range $98 \cdot 3-775$ ) $\mathrm{g} / 24 \mathrm{~h}$ on day 3 post-partum. By days 14 and 28 post-partum milk yields were $1.156(\mathrm{SD} 0.167) \mathrm{kg} / 24 \mathrm{~h}$.

A comparison between the mean daily milk yields for the present study and those obtained from the breast-expression studies of Roderuck et al. (1946) is presented in Fig. $2 b$. During the first $5 \mathrm{~d}$ post-partum there was no significant difference between the mean daily yields obtained by suckled infants and by breast-expression.

\section{Feeding frequency}

The first breast-feed commenced within 60 min of delivery and the newborn infants obtained 2.2 (range 0-5.0) g of mammary secretion at this feed. The infants breast-fed an average of six times in the first $24 \mathrm{~h}$ (range three to eight). The feeding frequency increased to more stable levels on day 2 post-partum with a mean of $7.6 \mathrm{feeds} / 24 \mathrm{~h}$ (range five to ten).

There was no significant correlation between milk yield and feeding frequency for the first $5 \mathrm{~d}$ post-partum; however, by day 14 and day 28 there was a significant positive correlation $(P<0.05 ; r 0.78, n 6)$ between milk yield and feeding frequency.

\section{Milk composition}

The mean daily changes in the concentration of lactose, total protein and fat in the mammary secretions of five women are shown in Fig. 3. The concentration of lactose increased from 


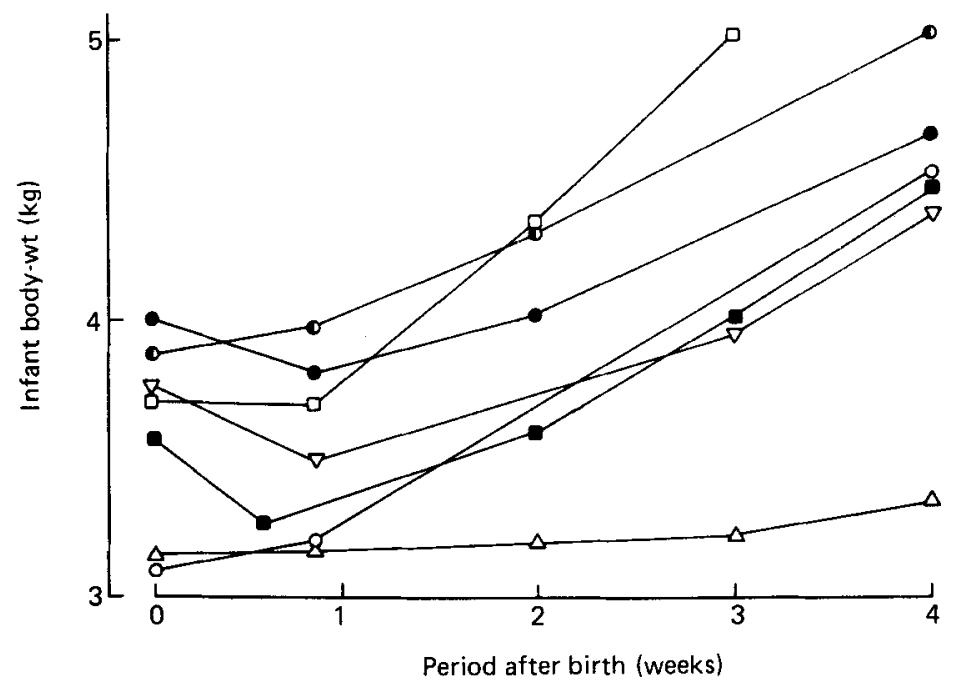

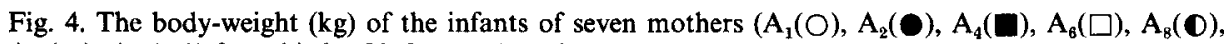
$\left.A_{11}(\triangle), A_{12}(\nabla)\right)$ from birth of infant to 4 weeks post-partum.

39.5 (SD 14.4) g/l on day 1 post-partum to 62.7 (SD 14.6) g/l on day 3 post-partum and was 67.9 (SD 9.4$) \mathrm{g} / 1$ by day 5 post-partum. There was a significant positive correlation $(P<0.001)$ between lactose concentration and milk yield for the first $5 \mathrm{~d}$ post-partum $(r$ $0 \cdot 76, n 22)$.

The concentration of total protein fell from 65.6 (SD 27.0) g/l on day 1 to 24.6 (SD 7.0) $\mathrm{g} / 1$ on day 3 . On day 5 the total protein concentration in breast milk samples was 23.5 (SD $8) \mathrm{g} / 1$. There was a significant negative correlation $(P<0.001)$ between total protein concentration in breast milk and milk yield $(r-0.74, n 22)$.

The concentration of fat in mammary secretions collected by women on day 1 was 17.7 (SD 5.2) g/l and was 20.3 (SD 13.4) g/l on day 3 and rose to 24.4 (SD 5.2) g/l on day 5 post-partum. No significant correlation was found between fat concentration in breast milk and milk yield for the first $5 \mathrm{~d}$ post-partum.

\section{Energy intake}

The energy content $(\mathrm{kJ} / \mathrm{g})$ of breast milk for five of the women was (mean and SD) $2 \cdot 7(0.4)$, $2 \cdot 4(0 \cdot 4), 2 \cdot 8(0 \cdot 6), 2 \cdot 6(0 \cdot 3), 2 \cdot 7(0 \cdot 3)$ and $2 \cdot 6(0 \cdot 3)$ for days $1,2,3,4,5$ and $14-28$ postpartum respectively. The mean intake of energy from breast milk for the infants was 0.12 (range 0.02-0.29), 0.59 (range 0.25-1.28), 1.44 (range 0.83-2.18), 1.69 (range 0.84-2.33), 1.87 (range $1.18-2.75$ ) and 2.99 (range $2.49-4.06$ ) $\mathrm{mJ} / 24 \mathrm{~h}$ for days $1,2,3,4,5$ and 14-28 post-partum respectively.

\section{Infant growth}

Infant weight from birth to 4 weeks post-partum is shown in Fig. 4 . The mean birth weight of infants studied was $3.59(\mathrm{SD} 0.35) \mathrm{kg}$. There was considerable variation in growth between infants. Whereas the infants of mothers $A_{1}$ and $A_{8}$ increased in weight from the time of birth to discharge from hospital, infants of mothers $A_{2}, A_{4}$ and $A_{12}$ lost weight over the same period and one infant had only a small increase in weight over the 4-week period. Neither this infant nor its mother $\left(\mathrm{A}_{11}\right)$ showed any sign of illness during the study.

There was a significant positive correlation between the daily increment change in weight 
of the infants and the total milk yield over the first $5 \mathrm{~d}(P<0.01 ; r 0.88, n 7)$, that is, infants of the mothers with the highest milk yield tended to lose less weight over the first week after birth.

\section{DIS CUSSION}

The most commonly used method of determining milk production for women who breast-feed their infants is the test-weighing procedure (Lonnerdal et al. 1976; Whitehead \& Paul, 1981). This method involves weighing the infant before and after a breast feed, and the increase in infant weight is considered to be the milk yield of the mother. The movement of the infant and lack of sensitivity of conventional balances has limited the accuracy of this method (McClelland et al. 1978). The development of the integrating electronic balance permits the accurate measurement of infant weight under conditions of moderate infant movement. However, in our hands even the integrating electronic balance cannot tolerate movements of older active infants (more than 4 months of age) and therefore we have used the change in maternal weight before and after breast-feeding to measure milk production during established lactation in women (Rattigan et al. 1981). A significant $(P<0.001)$ correlation, $r 0.85$, was found between the milk yield measured by the increase in infant weight using the integrating electronic balance and the decrease in maternal weight (Fig. 1). The slightly higher yields obtained by test-weighing the mother were probably due to sweating and insensible water losses which would tend to provide an overestimate of milk yield when the mother was test-weighed and an underestimate of milk yield when the infant was test-weighed. Nevertheless, these findings confirm that it is possible to obtain a similar estimate of milk consumed by the infant by test-weighing either the mother or the infant.

All infants in the present study were breast-fed within $60 \mathrm{~min}$ of delivery. The colostrum intake at this initial breast-feed was 2.2 (range $0-5.0$ ) $\mathrm{g}$. This probably represented an underestimate of milk intake as surface evaporation losses from the infant would be expected to be higher immediately post-partum. The average milk intake at each breast-feed during the first $24 \mathrm{~h}$ after birth was only $6.0 \mathrm{~g}$. As a result the infant's energy intake during the first $24 \mathrm{~h}$ of life was only 0.12 (range $0.02-0.29$ ) $\mathrm{mJ}$ for these infants who were breast-fed on demand from birth. Even this value may be an overestimate of energy intake since immunoglobulins form a large proportion of the protein fraction at this time (Kulski \& Hartmann, 1981) and the nutritive value of immunoglobulins to the newborn is not known. Metabolically, this low energy intake appears to be an undesirable situation because the infant's high value for the ratios, surface area:body-weight and head size:body size, and high critical temperature suggest that the infant would have a high demand for energy at this time. However, it is possible that the high concentration of antimicrobial proteins in a relatively small volume of secretion facilitates the efficient protection of the gastrointestinal and respiratory tracts at this time (Watson, 1980).

Milk yield increased rapidly after the 1st day post-partum and by day 5 had reached $844-876 \mathrm{~g} / 24 \mathrm{~h}$ in four of the women (Fig. $2 a$ ), that is, a value considered to be the maximum milk yield for women by many current workers (Whitehead, 1982). Three women $\left(A_{2}, A_{4}\right.$ and $\left.A_{5}\right)$ had significantly lower milk production on day 3 post-partum (Fig. $2 a$ ). However, the mother $\left(A_{2}\right)$ who remained in our study achieved normal milk yield by $14 \mathrm{~d}$ post-partum.

The only previous information on milk yield in women from delivery was published in 1946 (Roderuck et al. 1946) and obtained from mothers who fully expressed their breasts for the first $10 \mathrm{~d}$ of lactation. There was no significant difference between the day-by-day milk yield for the first $5 \mathrm{~d}$ post-partum between these mothers and the mothers in the present study (Fig. 2b) who breast-fed their infants. The findings of McClelland et al. (1978) for 
breast-milk yield from breast-feeding mothers from 2 to $28 \mathrm{~d}$ post-partum are also in agreement with the present study. Furthermore, there was no significant difference between the milk yield reported by Roderuck et al. (1946) for mothers at $10 \mathrm{~d}$ of lactation and the values observed at either 14 or $28 \mathrm{~d}$ post-partum (Fig. $2 b$ ), and these values were similar to those observed for Australian women at 1 month of lactation (Rattigan et al. 1981).

The increase in milk yield during the first $5 \mathrm{~d}$ of lactation was correlated $(r 0.76)$ with the increase in the concentration of lactose in the mammary secretion (Figs $2 a$ and 3). This relationship confirms the conclusion that the increase in the concentration of lactose in milk after birth provides an estimate of the timing of lactogenesis in women (Kulski et al. 1981) as in other species (Hartmann, 1973; Nicholas \& Hartmann, 1981). Although the lactose and fat profiles appear similar (Fig. 3), the increase in milk yield was not correlated with the increase in the concentration of fat in the mammary secretion. This apparent anomaly may be explained by the larger coefficient of variation (average $47 \%$ ) for the mean concentration of fat for the first $5 \mathrm{~d}$ of lactation compared with lactose (average $25 \%$ ). Whereas the initial increase in milk yield occurred on the second day after delivery (Fig. $2 a$ ), the mothers' observation of the acute feeling of milk 'coming in' occurred on the 3rd day post-partum in most women (Kulski et al. 1981). Although not all women who breast-fed their babies from birth sensed milk 'coming in', some of the mothers noted that milk yield increased before they sensed milk 'coming in'. These observations support our earlier suggestion (Kulski et al. 1977, 1981) that milk 'coming in' is a separate event to physiological lactogenesis in women. The physiological process leading to the acute sensation of milk 'coming in' remains unresolved.

The energy intakes for the infants when expressed as $\mathrm{mJ} / \mathrm{kg}$ per $24 \mathrm{~h}$ for either days 14 or 28 after birth are within the range calculated by Rattigan $e t$ al. (1981) for infants at 1 month after birth. However, the energy intakes are higher than the accepted values of Fomon (1964) and that recommended by WHO/FAO (1973) of $0.5 \mathrm{~mJ} / \mathrm{kg}$ for male infants during the first 2 months after birth. Furthermore, it has been suggested by Yeung $e t$ al. (1980) and Whitehead \& Paul (1981) that the latter recommendation is too high. However, the recent important findings of the dependent relationship between energy intake and the protein concentration in the diet in piglets (Williams, 1982) suggest that a reappraisal of infant feeding is required, particularly in view of the fact that human breast milk has one of the lowest concentrations of protein of any milk (Evans, 1959).

The authors wish to thank the volunteers who participated in the study. The present work was supported by the Wespac Fellowship from the K.E.M.H. Medical Research Foundation, Western Australia.

\section{REFERENCES}

Evans, D. E. (1959). Dairy Science Abstracts 21, 277-288.

Fomon, S. J., Owen, G. M. \& Thomas, L. N. (1964). American Journal of Diseases of Children 108, $601-604$.

Hartmann. P. E. (1973). Journal of Endocrinology 59, 231-247.

Hartmann, P. E. \& Kulski, J. K. (1978). Journal of Physiology (London) 275, 1-11.

Kulski, J. K. \& Hartmann, P. E. (1981). Australian Journal of Experimental Biology and Medical Science 59, 101-114.

Kulski, J. K., Smith, M. \& Hartmann, P. E. (1977). Journal of Endocrinology 74, 509-510.

Kulski, J. K., Smith, M. \& Hartmann, P. E. (1981). Australian Journal of Experimental Biology and Medical Science $59,405-412$.

Lonnerdal, B., Forsum, E. \& Hambraeus, L. (1976). American Journal of Clinical Nutrition 29, $1127-1133$.

McClelland, D. B. L., McGrath, J. \& Samson, R. R. (1978). Acta Paediatrica Scandinavica 271, Suppl., 3-20.

Martin, P. J. (1975). Clinica Chimica Acta 62, 79-88.

Maynard, L. A. \& Loosli, J. K. (1956). Animal Nutrition, 4th ed. York, Pennsylvania: McGraw-Hill.

Nicholas, K. R. \& Hartmann, P. E. (1981). Australian Journal of Biological Sciences 34, 435-443. 
Rattigan, S., Ghisalberti, A. V. \& Hartmann, P. E. (1981). British Journal of Nutrition 45, 243-249.

Roderuck, C., Williams, H. H. \& Macy, I. G. (1946). Journal of Nutrition 32, 267-283.

Snedecor, G. W. \& Cochran, W. G. (1978). Statistical Methods, 6th ed. Ames, lowa: Iowa State University Press. Watson, D. L. (1980). Australian Journal of Biological Sciences 33, 403-422.

Whitehead, R. G. (1982). Maternal Diet, Breastfeeding Capacity and Lactational Infertility. The United Nations University Food and Nutrition Bulletin. Suppl. 6.

Whitehead, R. G. \& Paul, A. A. (1981). Lancet ii, 161-163.

WHO/FAO (1973). Energy and Protein Requirements. Technical Report Series No. 522, Geneva: WHO.

Williams, 1. H. (1982). Proceedings of the Australian Society of Animal Production 14, $238-251$.

Yeung, D. L., Hall, J. \& Leung, M. (1980). Journal of the Canadian Dietetic Association 41, $48-52$. 